
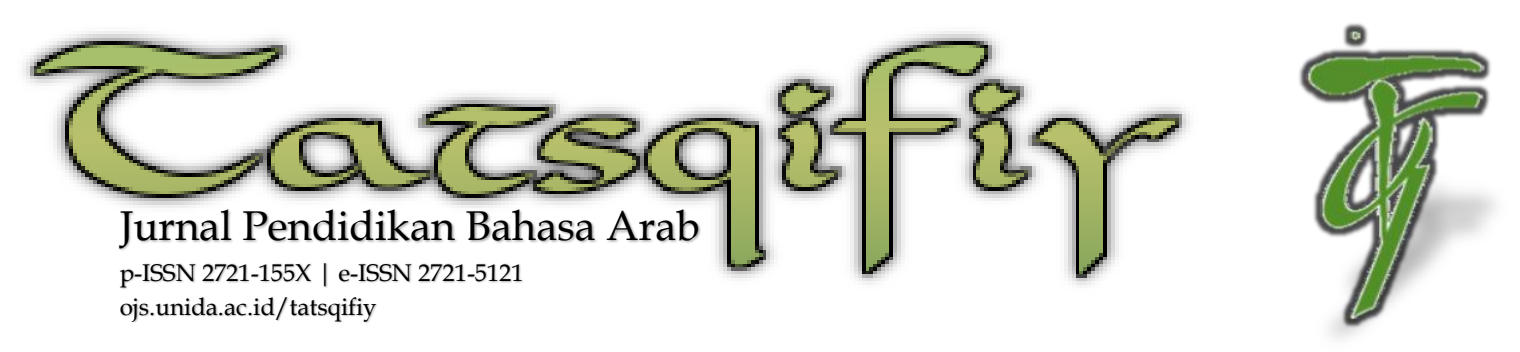

\title{
Pengaruh Program Matrikulasi terhadap Kemampuan Berbahasa Arab Mahasiswa Baru Pendidikan Bahasa Arab
}

\author{
Zelika Afaria ${ }^{1}$ \\ ${ }^{1}$ Program Studi Pendidikan Bahasa Arab, Fakultas Keguruan dan Ilmu Pendidikan \\ Universitas Djuanda Bogor, Jl. Tol Ciawi No.1 Kode Pos 35 Ciawi Bogor 16720
}

Volume 1 Nomor 2

Juli 2020: 101-111

DOI: $10.30997 /$ tjpba.v1i2.2803

Article History

Submission: 02-06-2020

Revised: 19-06-2020

Accepted: 24-06-2020

Published: 06-07-2020

Kata Kunci:

Bahasa Arab, Mahasiswa Baru, Program

Matrikulasi

Keywords:

Arabic Language, Matriculation Program, New Students

$\underline{\text { Korespondensi: }}$

(Zelika Afaria)

(085743246717)

(afaria.zelika@gmail.com)
Abstrak: Matrikulasi merupakan program untuk memberikan materi dasar dalam pembelajaran bahasa. Program ini mengakomodasi upaya penyetaraan kemampuan siswa baru dengan kemampuan dasar yang bervariasi dalam suatu pembelajaran, tetapi program ini masih jarang diimplementasikan dalam kurikulum Pendidikan Bahasa Arab. Penelitian ini bertujuan untuk mengetahui pengaruh keikutsertaan mahasiswa baru dalam program matrikulasi bahasa Arab terhadap kemampuan berbahasa arab. Pendekatan yang digunakan dalam penelitian ini adalah pendekatan kuantitatif menggunakan kuesioner. Pengumpulan sampel dilakukan melalui metode convenience sampling. Uji validitas dan reliabilitas dilakukan untuk mengelompokan data penelitian dan selanjutnya diuji menggunakan analisis regresi sederhana. Penelitian ini menunjukan bahwa keikutsertaan terhadap program matrikulasi bahasa Arab berkontribusi sebanyak 50,6\% terhadap kemampuan berbahasa arab mahasiswa baru Pendidikan Bahasa Arab. Penelitian selanjutnya diharapkan membahas desain materi dan metode yang digunakan dalam program matrikulasi bahasa Arab. Effect of The Matriculation Program to New Students'
Skill in The Arabic Language Study
Abstract: Matriculation is a program that provides the ba-
sic learning for language education. The program accommo-
dates students with different basic competence to reach the
same level in a study, but it is still rarely implemented in the
Arabic language education curriculum. This research aims
to know the effect of the participation in the matriculation
program to new students skill in the Arabic language
study. This research was conducted using quantitative
approach and questionnaire as the research tool. The samples
were gathered using convenience sampling technique. The
group of data is collected through validity and reliability test
and got analyzed with simple regression analysis. The re-

Tatsqifiy: Jurnal Pendidikan Bahasa Arab is licensed under a Creative Commons Attribution-Share Alike 4.0 International License. Copyright @ 2020 Universitas Djuanda. All Rights Reserved p-ISSN 2721-155X | e-ISSN 2721-5121 
Pengaruh Program Martikulasi terhadap Kemampuan Berbahasa Arab

Mahasiswa Baru Pendidikan Bahasa Arab

search shows that the participation in matriculation program takes $50,6 \%$ of contribution in determining new students skill in Arabic language study. The next research is expected to discuss the design and method used in matriculation program of Arab language study.

\section{PENDAHULUAN}

Bahasa adalah salah satu media komunikasi yang digunakan untuk berinteraksi dengan orang lain. Ada banyak sekali ragamnya di dunia ini. Karena dengan bahasa, seseorang bisa menyampaikan pikiran, ide, gagasan dan perasaannya. Oleh karena itu, keberadaan bahasa sangat penting bagi kelangsungan hidup manusia (Hidayat, 2012). Salah satu yang memiliki pengguna terbanyak adalah bahasa Arab (Khalilullah, 2011).

Bahasa Arab merupakan bahasa AlQuran yang dibaca oleh hampir seluruh umat muslim di dunia. (Rahmawati, 2019). Bahasa Arab juga merupakan bahasa yang ada didalam hadis dan hukum-hukum islam lainnya. Tidak salah, jika bahasa Arab mudah menyebar ke berbagai penjuru dunia, terutama dalam penyebaran Islam. Sebagai seorang muslim, maka diharapkan untuk mempelajari bahasa Arab sebagai kebutuhan (Hendra, 2013).

Di Indonesia, bahasa Arab mulai diperkenalkan sejak masa kanak-kanak awal (dibeberapa Taman Kanak-Kanak (TK) Islam), dan terus diajarkan hingga perguruan tinggi. Bahasa Arab pun menjadi materi wajib bagi pondok pesantren yang berdiri di Indonesia (Abdul Wahab, 2016). Tidak dipungkiri, bahwa keinginan belajar bahasa Arab di perguruan tinggi tidak hanya datang dari kalangan yang pernah mempelajarinya sebelumnya. Tetapi juga dari kalangan non-Arab yang tertarik untuk memulai mempelajari bahasa Arab di tingkat perguruan tinggi. Ketertarikan merupakan satu dari sekian faktor seseorang memilih program pembelajaran yang diikutinya (Nalim, 2012).

Di perguruan tinggi, pembelajaran bahasa Arab diharapkan lebih mendalam dan mendetail. Tetapi, ini akan menjadi sebuah tantangan jika peserta didik yang masuk dalam program studi bahasa Arab tidak memiliki kemampuan bahasa Arab dasar. Beraneka ragamnya latar belakang pendidikan peserta didik di tingkat sebelumnya, beraneka ragam pula tingkat pengeta- 
huan dan kemampuannya dalam berbahasa arab (Setiyawan, 2018).

Tentu ini harus menjadi perhatian bagi perguruan tinggi yang memiliki program studi bahasa Arab untuk menyiapkan program atau pembelajaran bahasa Arab dasar bagi peserta didik baru yang masuk dalam program studi tersebut (Helmanto, F. \& Hidayat, A., 2020). Jika perbedaan penguasaan kemampuan berbahasa Arab ini diabaikan, maka akan menimbulkan permasalahan terhadap proses pembelajaran. Peserta didik yang belum pernah mempelajari bahasa Arab akan merasa kesulitan memahami pelajaran yang disampaikan, karena perbedaan tingkat kemahiran dalam berbahasa Arab (Mufidah et al., 2019). Begitupun dengan peserta didik yang sudah pernah dan mahir dalam bahasa Arab akan bosan ketika pelajarannya terus diulang-ulang (Setiyawan, 2018).

Ada beberapa alternatif program yang bisa dilakukan oleh pihak lembaga pendidikan untuk mengatasi keberagaman latar belakang pendidikan dalam program studi bahasa Arab, antara lain: (1) membagi kelas ke dalam beberapa tingkatan sesuai dengan kemampuan berbahasa Arab, (2) melakukan program matrikulasi bahasa Arab, (3) menerapkan model dan strategi pembelajaran yang sesuai dengan kebutuhan (Setiyawan, 2018).

Salah satu program pembelajaran yang bisa digunakan untuk mengatasi permasalahan ini adalah dengan kelas matrikulasi bahasa Arab. Matrikulasi adalah program pembelajaran untuk peserta didik baru yang bertujuan untuk menyetarakan kompetensi bagi program studi yang memiliki peserta didik dengan keberagaman latar belakang pendidikan sebelumnya (Hikmawati, 2019).

Namun, kelas matrikulasi bahasa Arab ini masih jarang ditemui dalam kurikulum pembelajaran program studi Pendidikan Bahasa Arab (PBA) di perguruan tinggi. Lembaga pendidikan sudah selayaknya mengembangkan pendekatan melalui riset dan teori dari pakar untuk mendapatkan sumber pengetahuan yang memadai bagi peserta didik (Hanafi, 2013).

Pembelajaran Matrikulasi bahasa Arab mencakup pembelajaran dasar dalam bahasa Arab. Menurut Ferdinand de Saussure, awal mula bahasa adalah ujaran (lisan) (Muradi, 2014). Oleh karena itu, pembelajaran Matrikulasi 
Pengaruh Program Martikulasi terhadap Kemampuan Berbahasa Arab

Mahasiswa Baru Pendidikan Bahasa Arab

bahasa Arab yang disampaikan bertahap mulai dari kemampuan menyimak (mahaarah al-istima'), kemampuan berbicara (mahaarah al-takallum), kemampuan membaca (mahaarah al-qi$\left.r a^{\prime} a h\right)$ dan kemampuan menulis (mahaarah al-kitabah) (Sa'idah, 2016).

Dalam proses pembelajaran matrikulasi bahasa Arab, peserta didik juga dituntut untuk menguasai perbendaharaan mufrodat atau kosa kata bahasa Arab untuk menunjang kemudahan dalam pembelajaran dasar lainnya (Ahmad et al., 2019).

Berdasarkan paparan diatas, penelitian ini bertujuan untuk mengungkap seberapa besar pengaruh program matrikulasi bahasa Arab terhadap kemampuan berbahasa Arab mahasiswa baru program studi Pendidikan Bahasa Arab.

\section{METODE}

Metode yang digunakan dalam penelitian ini termasuk jenis penelitian survei dengan pendekatan kuantitatif. Data penelitian didapat dari kuesioner (dibuat oleh peneliti), yang kemudian dijawab oleh mahasiswa yang pernah mengikuti kelas matrikulasi bahasa Arab. Kuesioner berisi 31 pertanyaan yang pilihan jawabannya menggunakan skala likert. Skala likert digunakan untuk mengukur sikap, pendapat, dan persepsi seseorang atau sekelompok tentang kejadian atau gejala sosial (Sudaryono, 2018).

Peneliti menggunakan teknik nonprobability sampling melalui metode convenience sampling. Teknik pengambilan sampel dengan metode convenience sampling ini dilakukan untuk menguji kuesioner atau juga pada penelitian eksplorasi (Sudaryono, 2018).

Populasi dalam penelitian ini adalah mahasiswa PBA di salah satu Perguruan Tinggi di Jakarta. Sedangkan sampel penelitiannya adalah perwakilan mahasiswa PBA dari masing-masing semester yang pernah mengikuti kelas matrikulasi bahasa Arab.

Pertanyaan dalam kuesioner meliputi: 1) keikutsertaan dalam kelas matrikulasi; 2) metode pembelajaran yang dilakukan oleh dosen; 3) materi pembelajaran; 4) pelaksanaan evaluasi; 5) hasil pembelajaran matrikulasi bahasa Arab. Hasil kuesioner yang terkumpul dianalisis untuk mengetahui keabsahan data.

Hipotesis awal dari penelitian ini adalah pengaruh variabel $X$ terhadap variabel Y. Variabel X merupakan kelas 
matrikulasi dan variabel $\mathrm{Y}$ merupakan kemampuan berbahasa Arab.

$\mathrm{H}_{0}=$ Kelas matrikulasi tidak berpengaruh terhadap kemampuan berbahasa Arab peserta didik baru PBA $\mathrm{H}_{1}=$ Kelas matrikulasi berpengaruh terhadap kemampuan berbahasa Arab peserta didik baru PBA

\section{HASIL \& PEMBAHASAN \\ Hasil}

Uji validitas menggunakan SPSS untuk variabel $X$ yaitu 31 pertanyaan. Ada 9 pertanyaan dinyatakan valid dan 22 pertanyaan dinyatakan tidak valid.

Uji reliabilitas menggunakan SPSS dengan metode Cronbach's Alpha (a). Berdasarkan hasil uji validitas sebelumnya, pertanyaan kuesioner valid berjumlah 9 pertanyaan. Oleh karena itu, hanya 9 pertanyaan tersebut yang diolah datanya.

Dari hasil perhitungan uji reliabilitas menggunakan SPSS, didapatkan nilai Cronbach's Alpha adalah 0,983.

Uji Hipotesis Penelitian dapat dilihat pada tabel 1, 2 dan 3 dibawah ini.

Tabel 1 Hasil Perhitungan Koefisien Korelasi Pengaruh Variabel X terhadap Variabel $Y$

Model Summary ${ }^{b}$

\begin{tabular}{|c|c|c|c|c|}
\hline Model & $\mathrm{R}$ & $\begin{array}{c}\mathrm{R} \\
\text { Square }\end{array}$ & $\begin{array}{l}\text { Adjusted } \\
\text { R Square }\end{array}$ & $\begin{array}{l}\text { Std. Error } \\
\text { of the } \\
\text { Estimate }\end{array}$ \\
\hline
\end{tabular}

\begin{tabular}{lllll}
\hline 1 & $.711^{\mathrm{a}}$ & .506 & .341 & 5.212 \\
\hline
\end{tabular}

a. Predictors: (Constant), Angket

b. Dependent Variable: Nilai

Berdasarkan hasil analisis pada Tabel 1, diketahui nilai $R$ square adalah bernilai positif 0,506 (Noviandini, 2012). Hal ini dapat diinterpretasikan bahwa terdapat pengaruh variabel $(X)$ terhadap variabel $(Y)$.

Tabel 2 Hasil Perhitungan Persamaan Garis Regresi Pengaruh Variabel X terhadap Variabel $Y$

\section{Coefficients $^{\mathrm{a}}$}

\begin{tabular}{|c|c|c|c|c|c|}
\hline \multirow[t]{2}{*}{ Model } & \multicolumn{2}{|c|}{$\begin{array}{l}\text { Unstandardized } \\
\text { Coefficients }\end{array}$} & $\begin{array}{c}\text { Standa } \\
\text { rdized } \\
\text { Coeffic } \\
\text { ients }\end{array}$ & \multirow[t]{2}{*}{$\mathrm{T}$} & \multirow[t]{2}{*}{ Sig. } \\
\hline & B & $\begin{array}{l}\text { Std. } \\
\text { Error }\end{array}$ & Beta & & \\
\hline $\begin{array}{l}\text { (Cons } \\
\tan t)\end{array}$ & 59.301 & 17.569 & & 3.375 & .043 \\
\hline $\begin{array}{c}\text { Angk } \\
\text { et }\end{array}$ & .852 & .486 & .711 & 1.751 & .178 \\
\hline
\end{tabular}

a. Dependent Variable: Nilai

Tabel 3 Hasil Perhitungan Pengujian Signifikasi Koefisien Regresi Pengaruh Variabel X terhadap Variabel $Y$

\begin{tabular}{cccccc}
\multicolumn{6}{c}{ ANOVA $^{\mathbf{a}}$} \\
\hline \multirow{2}{*}{ Model } & $\begin{array}{c}\text { Sum of } \\
\text { Squares }\end{array}$ & Df & $\begin{array}{c}\text { Mean } \\
\text { Square }\end{array}$ & F & Sig. \\
\hline Regression & 83.317 & 1 & 83.317 & 3.068 & $.178^{\mathrm{b}}$ \\
Residual & 81.483 & 3 & 27.161 & & \\
Total & 164.800 & 4 & & & \\
\hline
\end{tabular}

a. Dependent Variable: Nilai

b. Predictors: (Constant), Angket

Pengaruh keikutsertaan kelas matrikulasi bahasa Arab (X) terhadap kemampuan berbahasa Arab (Y) Hipotesis statistik yang dibuktikan : 
Pengaruh Program Martikulasi terhadap Kemampuan Berbahasa Arab Mahasiswa Baru Pendidikan Bahasa Arab

$\mathrm{H}_{0}=$ Jika sig. $<0,05$ maka pengaruh antara keikutsertaan kelas matrikulasi bahasa Arab (X) dengan kemampuan berbahasa Arab (Y) signifikan

$\mathrm{H}_{1}=$ Jika sig. $>0,05$ maka pengaruh antara keikutsertaan kelas matrikulasi bahasa Arab (X) dengan kemampuan berbahasa Arab (Y) tidak signifikan

Pengujian hipotesis melalui analisa regresi, di mana dari hasil pengujian pada tabel 2 menginterpretasikan pengaruh variabel $X$ terhadap variabel $Y$, yaitu $Y=59,30+0,852 X$

Untuk membuktikan hipotesis tersebut, maka bisa dilihat nilai sig. pada tabel 3. Nilai sig. 0,178 >0,05 maka $\mathrm{H}_{0}$ ditolak.

\section{Pembahasan}

Kuesioner yang dibuat peneliti dilakukan uji validitas untuk mengetahui aspek kecermatan dan ketepatan hasil pengukuran (Hendryadi, 2017). Uji validitas dilakukan menggunakan korelasi dari setiap pertanyaan, dengan skor total dari seluruh pertanyaan yang ada diuji. Berdasarkan uji pearson menggunakan SPSS, didapatkan hasil sig. (2tailed) yang kemudian dibandingkan dengan $R$ tabel. $R$ tabel untuk jumlah 5 responden adalah 0,878 . Pertanyaan dinya- takan valid apabila sig. (2-tailed) > 0,878, sedangkan jika sig. (2-tailed) $<0,878$ maka pertanyaan dianggap tidak valid.

Uji reliabilitas pada penelitian ini menggunakan uji statistika Cronbach's Alpha. Hasil uji ini menunjukan apakah kuesioner yang digunakan reliabel atau tidak (Alfian \& Putra, 2017). Reliabilitas suatu kuesioner dapat dikatakan baik jika memiliki nilai Cronbach's Alpha > 0,60 (Cahyani et al., 2016). Hasil uji Cronbach's Alpha penelitian ini adalah 0,983, maka dapat disimpulkan bahwa kuesioner ini reliabel.

Setelah uji reliabilitas, dilanjutkan uji hipotesis menggunakan SPSS dengan fungsi uji analisis regresi sederhana. Hasil uji ini merupakan koefisien determinasi ( $R$ square) 0,506 yang bernilai positif (Noviandini, 2012). Karena bernilai positif, maka dapat diinterpretasikan bahwa adanya pengaruh pengaruh dari keikutsertaan kelas matrikulasi $(\mathrm{X})$ terhadap kemampuan berbahasa Arab peserta didik baru PBA (Y) sebesar 50,6\%. Sedangkan $49,4 \%$ berasal dari faktor lain.

Hasil pengujian hipotesis didapatkan nilai sig. 0,178 >0,05. Berdasarkan tingkat signifikasi $\mathrm{a}=0,05$, maka $\mathrm{H}_{0}$ di- 
tolak. Artinya terdapat pengaruh keikutsertaan kelas matrikulasi bahasa Arab $(X)$ terhadap kemampuan berbahasa Arab peserta didik baru PBA (Y) tidak signifikan.

Kelas matrikulasi bahasa Arab merupakan salah satu cara untuk memberikan pembelajaran bahasa Arab dasar untuk peserta didik PBA. Pembelajarannya meliputi keterampilan menyimak, membaca, berbicara, dan menulis (Kaptiningrum, 2016). Keterampilan ini diawali dengan pengenalan kosakata (mufrodat) bahasa Arab, isim (kata benda) dan fi'il (kata kerja) (Loeis, 2011).

Salah satu metode yang dapat digunakan untuk pengenalan kosa kata $(m u-$ frodat) adalah thariqah mubasyarah. Metode ini merupakan metode langsung dengan media di sekitar peserta didik yang dapat dipraktikan setiap harinya (Sudjani \& Gunadi, 2020). Pengenalan kosakata ini sangat penting bagi peserta didik yang baru belajar bahasa Arab, karena banyaknya pola pembentukan kata yang bentuknya beragam, baik melalui cara derivasi (tasrif isytiqaqi) atau cara infleksi (tasrif i'rabi) yang harus dipahami sebelum mempelajari keterampilan lainnya (Fahrurrozi, 2014).
Pembelajaran kelas matrikulasi dilanjutkan dengan keterampilan menyimak (maharaah istima'). Keterampilan menyimak merupakan kemampuan seseorang untuk memahami kalimat yang diucapkan oleh lawan bicara atau media tertentu (Hasan, 2017). Salah satu media yang digunakan dalam pembelajaran ini adalah media audio visual (Rahmawati, 2019). Dengan media ini, peserta didik dapat lebih cepat memahami suatu kalimat karena adanya penggambaran dari ujaran yang diucapkan.

Keterampilan menyimak juga merupakan dasar dari keterampilan berbicara, agar tercipta komunikasi dua arah antara pembicara dan pendengar (Khalilullah, 2011). Keterampilan berbicara dapat dikembangkan dengan model kooperatif. Model ini, menggunakan kelompok teman sebaya sebagai media pembelajaran. Dengan media ini, peserta didik diharapkan tidak merasa canggung untuk berkomunikasi sehingga akan lebih mudah untuk mengembangkan kemampuannya. Namun, media ini juga harus didampingi dengan aturan dan target, agar tetap fokus untuk mencapai tujuan pembelajaran (Azis et al., 2013). 
Pengaruh Program Martikulasi terhadap Kemampuan Berbahasa Arab Mahasiswa Baru Pendidikan Bahasa Arab

Materi kelas matrikulasi selanjutnya adalah membaca dan menulis. Bahasa Arab memiliki huruf yang berbeda dari huruf latin yang biasa digunakan oleh masyarakat di Indonesia. Oleh karena itu, perlu keterampilan khusus untuk membaca, memahami dan menulis teks berbahasa Arab (Hai \& Harianto, 2017). Keterampilan membaca merupakan kemampuan dalam mengetahui kandungan suatu teks yang mengubah lambang tulisan menjadi bunyi (Sudiarti, 2015). Masalah yang biasanya dihadapi peserta didik adalah bentuk perubahan kata dalam bahasa Arab yang hampir mirip, sehingga diperlukan pemahaman yang baik untuk menerjemahkannya. Begitupun dalam keterampilan menulis, peserta didik diharapkan mampu untuk mengungkapkan isi pikirannya melalui tulisan-tulisan yang sesuai dengan kaidah penulisan dalam bahasa Arab (Setiadi, 2017).

Evaluasi pembelajaran dilakukan dengan memasukkan semua unsur yang telah dipelajari. Evaluasi ini bertujuan untuk mengetahui berhasil atau tidaknya proses belajar mengajar (Kosbandhono, 2013). Evaluasi juga dilakukan pada setiap pokok materi, sehingga pendidik mengetahui peningkatan pemahaman dari peserta didik, yang kemudian menjadi bahan acuan untuk menentukan materi pembelajaran berikutnya.

Semua keterampilan yang ada dalam pembelajaran matrikulasi ini, sebaiknya masuk dalam pokok pembahasan yang dipelajari didalam kelas. Berdasarkan jawaban kuesioner yang ada, responden menganggap bahwa keterampilan yang dipelajari di kelas matrikulasi bahasa Arab mampu meningkatkan kemampuan berbahasa Arabnya dan membantu dalam mengikuti materi pembelajaran pada tingkat selanjutnya. Sejalan dengan penelitian ini bahwa adanya pengaruh keikutsertaan kelas matrikulasi bahasa Arab terhadap kemampuan berbahasa Arab peserta didik baru PBA sebanyak 50,6\%, sedangkan sisanya dipengaruhi oleh faktor lain.

\section{SIMPULAN}

Matrikulasi bahasa Arab adalah salah satu program pembelajaran untuk mengatasi keberagaman peserta didik yang memilih program studi Pendidikan Bahasa Arab. Namun, program ini masih belum banyak dimplementasikan oleh perguruan tinggi yang memiliki program studi tersebut. Se- 
dangkan dalam realitanya, tidak semua peserta didik yang memilih program studi tersebut memiliki kemampuan dasar bahasa Arab.

Berdasarkan penelitian ini, matrikulasi bahasa Arab mempunyai pengaruh terhadap kemampuan bahasa Arab mahasiswa baru PBA sebesar 50,6\%. Alangkah baiknya jika perguruan tinggi yang memiliki program studi pendidikan bahasa Arab membuat standar kurikulum yang mampu untuk mendukung pengembangan pembelajaran bahasa Arab bagi peserta didik yang baru belajar bahasa Arab.

Untuk itu, penelitian ini bisa dikatakan sebagai awal untuk penelitian selanjutnya mengenai program matrikulasi bahasa Arab. Diharapkan untuk selanjutnya dapat meneliti desain materi dan juga metode yang digunakan dalam program matrikulasi bahasa Arab.

\section{DAFTAR PUSTAKA}

Abdul Wahab, M. (2016). Standarisasi

Kurikulum Pendidikan Bahasa

Arab Di Perguruan Tinggi

Keagamaan Islam Negeri.

Arabiyat : Jurnal Pendidikan Bahasa

Arab Dan Kebahasaaraban, 3(1), 32-

51.

https://doi.org/10.15408/a.v3i1.3 187

Ahmad, M., Akzam, I., \& Yunita, Y.
(2019). Pengaruh Program Kelas

Bahasa Arab pada Lembaga

CELAD terhadap Penguasaan

Mufrodat (Kosa Kata) Mahasiswa.

Al-Hikmah: Jurnal Agama Dan Ilmu

Pengetahuan, 16(1), 58-77.

https:// doi.org/10.25299/jaip.201 9.vol16(1).2853

Alfian, R., \& Putra, P. M. A. (2017). Uji

Validitas dan Reliabilitas

Kuesioner Medication Adherence

Report Scale (Mars) terhadap

Pasien Diabetes Mellitus. Jurnal

Ilmiah Ibnu Sina, 2(2), 176-183.

Azis, S. A., Herdah, H., \& Jufri, M.

(2013). Implementasi Model

Pembelajaran Kooperatif

Mahasiswa Program Studi Bahasa

Arab STAIN Parepare (Studi

Pengembangan Pembelajaran Mata

Kuliah Serumpun). Jurnal

Kuriositas, 1(6), 81-102.

Cahyani, N. M., Indriyanto, E., \& Masripah, S. (2016). Uji Validitas

dan Reliabilitas Terhadap Implementasi Aplikasi Penjualan dan Pembelian. Information System for Education and Professionals, 1(1), 21-34.

Fahrurrozi, A. (2014). Pembelajaran Bahasa Arab : Problematika Dan Solusinya. ARABIYAT: Jurnal Pendidikan Bahasa Arab Dan Kebahasaaraban, 1(2). https://doi.org/10.15408/a.v1i2.1 $\underline{137}$

Hai, K. A., \& Harianto, N. (2017). Efektivitas Pembelajaran Qira'ah Pada Program Studi Pendidikan Bahasa Arab Fakultas Ilmu Budaya Universitas Jambi. Jurnal Titian, 1(2), 128-141.

Hanafi, A. H. (2013). Lembaga

Pendidikan Tinggi Islam: Harapan, Tantangan, Paradigma, Dan Peranan Bahasa Arab. Jurnal Al- 
Pengaruh Program Martikulasi terhadap Kemampuan Berbahasa Arab

Mahasiswa Baru Pendidikan Bahasa Arab

Fikrah, 1(1), 17-28.

https://doi.org/10.31958/JAF.V1I 1.347

Hasan. (2017). Keterampilan Mengajar

Bahasa Arab Materi Istima

Menggunakan Media Lagu. Jurnal

Ilmiah Al Qalam, 10(19), 127-147.

Helmanto, F. \& Hidayat, A. (2020).

Deskripsi Karakter: Pembukaan

Populer dalam Cerita Pendek

Bahasa Arab. Tatsqifiy: Jurnal

Pendidikan Bahasa Arab 1(1), 11-18

Hendra, F. (2013). Persepsi Mahasiswa

terhadap Proses Pembelajaran

Kemahiran Bahasa (Mata Kuliah

Kemahiran Bahasa Arab di

Program Studi Sastra Arab,

Fakultas Sastra, Universitas Al

Azhar Indonesia). JURNAL Al-

AZHAR INDONESIA SERI

HUMANIORA, 2(1), 66-86.

https://doi.org/10.36722/sh.v2i1. $\underline{118}$

Hendryadi. (2017). Validitas Isi: Tahap

Awal Pengembangan Kuesioner.

Jurnal Riset Manajemen Dan Bisnis

(JRMB) Fakultas Ekonomi UNIAT,

2(2), 169-178.

Hidayat, N. S. (2012). Problematika

Pembelajaran Bahasa Arab. Jurnal

Pemikiran Islam, 37(1), 82-89.

http:/ / ejournal.uin-

suska.ac.id/index.php/Anida/arti

cle/view/315

Hikmawati, S. A. (2019). Desain Silabus

Matrikulasi Pembelajarab Bahasa

Arab Bagi yang Melanjutkan ke

Jenjang PTKI/PTKIN. Muhadasah:

Jurnal Pendidikan Bahasa Arab, 1, 51-

58.

Kaptiningrum, P. (2016). Efektifitas

Program Matrikulasi Bahasa

Untuk Meningkatkan Kemampuan

Speaking Mahasiswa STAIBN

Tegal. Jurnal Shahih, 1(2), 149-165.
Khalilullah, M. (2011). Strategi

Pembelajaran Bahasa Arab Aktif

(Kemahiran Istima' Dan

Takallum). Jurnal Sosial Budaya, 8(2), 219-235.

http:/ / download.portalgaruda.org

$\angle$ article.php? article $=275520 \& v a l=7$

161\&title=STRATEGI

PEMBELAJARAN BAHASA

ARAB AKTIF (KEMAHIRAN

ISTIMAâ€TM DAN TAKALLUM)

Kosbandhono, E. (2013). Esesmen dan

Evaluasi untuk Maharah Istima'.

Arabia, 5(1), 1-12.

Loeis, W. (2011). Metode Langsung dalam Pembelajaran Bahasa Arab. Jurnal Turats, 7(2), 62-70.

https://doi.org/10.24252/diwan.v $\underline{3 i 1.2915}$

Mufidah, N., Sa'adah, N., \& Kholis, N. (2019). Strategi Multilanguage untuk Pembelajaran Bahasa Arab: Studi di Ma'had Mahasiswa. Jurnal Almakrifah, 16(1), 1-10.

https://doi.org/10.1017/CBO9781 $\underline{107415324.004}$

Muradi, A. (2014). Pendekatan

Komunikatif Dalam Pembelajaran

Bahasa Arab. ARABIYAT: Jurnal

Pendidikan Bahasa Arab Dan

Kebahasaaraban, 1(1), 29-48.

https://doi.org/10.15408/a.v1i1.1 129

Nalim. (2012). Memilih Program Studi Pendidikan Bahasa Arab Stain. Forum Tarbiyah, 10(2), 214-235.

Noviandini, N. C. (2012). Pengaruh Persepsi Kebermanfaatan, Persepsi Kemudahan Penggunaan, dan Kepuasan Wajib Pajak terhadap Penggunaan E-Filling bagi Wajib Pajak DI Yogyakarta. Jurnal Nominal, 1(1), 15-22.

Rahmawati, N. (2019). Pengaruh Media Audio Visual terhadap 
Pemahaman Maharoh Istima'

Bahasa Arab. IQ (Ilmu Al-Qur'an): Jurnal Pendidikan Islam, 2(02), 217231.

https://doi.org/10.37542/iq.v2i02. $\underline{34}$

Sa'idah, R. (2016). Strategi

Pembelajaran Bahasa Arab di ITC ( Islamic Training Center ) Pare.

Realita, 14(1), 22-34.

Setiadi, S. (2017). Peningkatan

Keterampilan Kitabah Arabiyah

Mahasiswa melalui Metode Tutor

Sebaya. Jurnal Al Bayan: Jurnal

Jurusan Pendidikan Bahasa Arab, 9(1), 31-39.

https://doi.org/10.24042/albayan. v9i1.1094

Setiyawan, A. (2018). Problematika

Keragaman Latar Belakang

Pendidikan Mahasiswa Dan

Kebijakan Program Pembelajaran

Bahasa Arab. Arabiyat : Jurnal

Pendidikan Bahasa Arab Dan

Kebahasaaraban, 5(2), 195-213.

https://doi.org/10.15408/a.v5i2.6

$\underline{803}$

Sudaryono. (2018). Metodologi Penelitian (2nd ed.). Raja Grafindo Persada.

Sudiarti, S. (2015). Peningkatan

Keterampilan Membaca Teks Arab

Gundul melalui Aktifitas Membaca

Intensif Berbasis Gramatikal :

Studi Kasus Mahasiswa Bahasa

dan Sastra Arab IAIN STS Jambi.

Fenomena, 7(1), 29-42.

https://doi.org/10.21093/fj.v7i1.2

64

Sudjani, D. H., \& Gunadi, G. (2020).

Thariqah Mubasyarah: Metode

Pembelajaran Bahasa Arab pada

Perguruan Tinggi. Tatsqify: Jurnal

Pendidikan Bahasa Arab, 1(1), 39-46. 